\title{
Inside Nigeria's Internally Displaced Persons Camps: Safe Haven or Den of Marauders
}

\author{
James E. Archibong \\ Department of Jurisprudence and International Law, Faculty of Law, University of Calabar, Nigeria \\ Email: jarchibong@yahoo.com
}

\author{
Article History \\ Received: 30 November, 202 \\ Revised: 19 December, 2021 \\ Accepted: 27 December, 2021 \\ Published: 31 December, 2021 \\ Copyright (C) 2021 ARPG \& \\ Author \\ This work is licensed under the \\ Creative Commons Attribution \\ International \\ (c) (1) CC BY: Creative \\ Commons Attribution License \\ 4.0
}

\begin{abstract}
In Nigeria, the internal displacement of civilians dates back to the era of the pogrom and attendant civil war in the 1960 s. Subsequent cases were attributable to natural and human-made factors. The flare-up of the Boko Haram insurgency in 2009 has over time caused the large-scale displacement of civilians in the northeast region. In line with humanitarian principles, the government created various camps to accommodate internally displaced persons (IDPs), where they could receive humanitarian assistance. This work examines harsh conditions in the camps, amid widespread shortages and abuses. It has been established that IDPs have been subjected to sexual exploitation and abuse (SEA) by state officials. Violations of this nature, which occur in the context of armed conflict, constitute crimes punishable under national and international laws. However, the government has not held anyone accountable, thus turning the IDP camps from safe haven to dens of predators. It is therefore recommended that individuals responsible for sexual abuses and other violations should be prosecuted. The government should rejig security, tackle corruption in the camps and ensure relief materials get to the IDPs. The government should address the conflict decisively to enable safe return of IDPs to their traditional homes.
\end{abstract}

Keywords: Internally displaced persons IDPs); Boko haram; Insurgency; Sexual exploitation and abuse; International humanitarian law.

\section{Introduction}

Internal displacement, according to the United Nations Guiding Principles on Internal Displacement, relates to persons dislocated within the territory of a state (UN Office for the Coordination of Humanitarian Affairs, 2004; United Nations High Commissioner for Refugees (UNHCR), 1998). Displaced persons assume the character of refugees, if they move beyond the frontier of their state of residence. Internal displacement is a major global challenge, as humans in every part of the world encounter dislocations occasioned by several factors, some being natural, while others are man-made (Global Protection Cluster; Medecins Sans Frontieres; Okon (2018): 28). From natural disasters caused by tsunamis, whirl winds and earthquakes, to human rights violations and armed conflicts waged across the globe, humanity has faced many severe hazards and displacements, and has continuously tried to solve the existential crises (Olarenwaju et al., 2019). In most cases, temporary residence or camps are erected to gather and care for victims of conflicts or disasters who survived, but lost their homes. As of December 2020, the number of IDPs globally stood at 55 million (Internal Displacement Monitoring Centre).

Over the years, many people in Nigeria have suffered displacement due to natural and man-made disasters, and conflicts. In the process, hundreds of homes have been destroyed, resulting in displacement of thousands of people. The government usually establish camps for victims of such disasters at various locations and rehabilitate them temporarily. However, man-made disasters or needless conflicts account for nearly all of the displacement in Nigeria. In addition to the ongoing insurgency, banditry, communal clashes and farmers-herders conflict have played a major role in the escalation of the problem by ravaging and utterly destroying several communities, sending their inhabitants into temporary camps (Nextier SPD, 2020). The latest estimate is put at over million people (International Organization for Migration, 2021).

The IDPs in Nigeria face various degrees of exploitation, abuses and oppression in the hands of personnel saddled with the responsibility of their safety and well-being. This paper analyses human rights and international humanitarian law (IHL) violations, sexual abuses, gender violence and general insecurity leading to serious injuries and in some cases deaths in IDPs camps in northeast Nigeria; and government ineptitude and unwillingness to address these problems. It examines internal displacement against the backdrop of the provisions of IHL. This is so because the Boko Haram insurgency has been classified as a non international armed conflict, and therefore 
governed by international as well as Nigerian laws (Ibanga and Archibong, 2018). In this context, the discussion will incorporate aspects of the Geneva Conventions and Additional Protocol II on protection and care for IDPs, against the backdrop of the nasty reports and violations from various IDP camps.

\subsection{Internal Displacement in Nigeria}

The first major case of internal displacement in Nigeria occurred in 1966 and continued throughout the civil war from 1967 to1970 (Global IDP Project, 2002; Olarenwaju et al., 2019). This was precipitated by ethnic strain between the Igbos of Eastern region and the Hausa /Fulani people of the North, which led to massacres of both sides. Igbo people resident in the north were encouraged by Colonel Odumegwu Ojukwu, Governor of the Eastern Region, and later Head of State of breakaway Biafra, to return home where their safety could be guaranteed (Goetz, 2001). In the ensuing hostilities, some two million people died and ten million people became internally displaced (Global IDP Project, 2002; Goetz, 2001). After the civil war and resettlement of displaced people, Nigeria has continued to witness internal displacement associated with conflicts. Communal conflicts, ethnic rivalry and violent boundary clashes have over the years taken great toll on civilians, uprooting thousands of people from their homes (Global IDP Project, 2002; Okon, 2018). The hostilities and military campaign against militants and oil thieves in the Niger Delta also caused significant displacement of civilians (Ibeanu, 1998).

Since the commencement of the insurgency in 2009, Nigeria has been grappling with a major wave of displacement. Boko Haram took up arms following the death of its mentor, Mohammed Yusuf, in police detention (Campbell, 2014). The armed rebellion, along with the counterinsurgency operations by the Nigerian armed forces, has left in its trail massive destruction of lives and property; and dislodged over 2 million people from their dwelling. They end up either as refugees in neighbouring Cameroon, Chad and Niger or internally displaced and camped in several cities across northern Nigeria and Abuja. Women and children constitute more than half of the population of IDPs. While most of the victims have sought shelter in government instituted IDPs camps, some have fled to other places to seek for survival. The wrecking challenges of internal displacement are enormous both on the victims and government.

\subsection{IDPs Under International Humanitarian Law}

Victims of displacement often suffer cruel effects of dislocation such as deprivation of food, educational opportunities, and healthcare (International Committee of the Red Cross, 2017). They are also exposed to arbitrary detention, enforced disappearances, forced recruitment and human trafficking. For this reason, IDPs are protected under IHL, a branch of international law that protects persons who do not take part in conflict (International Committee of the Red Cross, 2017). It embodies significant provisions aimed at ensuring that, in the event of displacement, IDPs are protected and provided with assistance at all levels (International Committee of the Red Cross, 2017). The insurgency in Nigeria is categorised as a non-international armed conflict and therefore governed by the 1949 Geneva Conventions of and Additional Protocol (AP) II of 1977 and other international legal instruments (Ibanga and Archibong, 2018). With regard to IDPs, Article 3 common to the Geneva Conventions offers them protection, as long as they are involved in fighting. Article 17 of AP II prohibits compulsory relocation of civilians, and where it occurs because of security reasons, "all possible measures shall be taken in order that the civilian population may be received under satisfactory conditions of shelter, hygiene, health, safety and nutrition" Customary international law (Rule 131) and the 1969 Kampala Convention also provide protection, support and care for IDPs. The UN guidelines on internal displacement, 2004 deal with the needs of IDPs globally, and identify certain rights and guarantees germane to them. While the aforementioned instruments specifically focus on the needs of displaced persons, all other forms of protection and rights bestowed on the civilian population unsettled by armed conflict are applicable to them.

Nigeria is State party to these international instruments and has an obligation to uphold them. It has also evolved a code known as National Policy on Internally Displaced Persons in Nigeria, which affirms the basic rights of citizens enshrined in the 1999 Constitution (National Policy on Internally Displaced Persons in Nigeria, 2012). The Policy recognizes the subjection of women and children and accords them special guarantees. It sets out standards on the delivery of humanitarian aids. Following the large number of IDPs in the northeast, the federal and state governments established camps in Borno, Adamawa and Yobe States in order to provide protection and support to the displaced persons. Camps have also been established in Abuja for displaced persons. The government mobilized its agencies and made huge budgetary provision for that purpose.

\subsection{IDPs and Humanitarian Law Obligations of the Government}

The conflict with Boko Haram insurgents has led to a large-scale displacement, which the UN described as the biggest humanitarian crunch in Africa (UN Human Rights Council, 2017). Whenever displacement occurs, those affected are eligible for various basic protections and rights. The government owes the displaced persons responsibility to provide humanitarian aids, such as food, shelter, medical care, protection and psychosocial counseling (National Policy on Internally Displaced Persons in Nigeria, 2012). In response to humanitarian needs of the IDPs, agencies of government have been deployed to manage the camps. The Borno State Emergency Management Agency (SEMA) and the National Emergency Management Agency (NEMA) are principally in charge of distribution of food, medicine, clothes, and beddings and other materials (Human Rights Watch, 2016). The federal government inaugurated the Presidential Committee on North-East Initiative (PCNI), with huge budgetary allocation to provide relief materials to IDPs (Ameh, 2018). 
The government agencies work in collaboration with local and international non-governmental organizations and United Nations agencies such as International Organisation for Migration (IOM), UN High Commission for Refugees (UNHCR), World Food Programme (WFP) and International Committee of the Red Cross (ICRC). Others are Medecins Sans Frontiers, United Nations Children Fund (UNICEF), International Rescue Committee (IRC) and National Red Cross Society, among others. Donations from these and other organisations have made significant impact on the lives of the IDPs (ICRC, Nigeria, Assistance to IDPs).

\subsection{Conditions in the IDPs Camps: A Humanitarian Nightmare}

Amid the huge government expenditure, there is an avalanche of complaints of shortages and rights violations in the camps (NAN, 2019; Sahara Reporters, 2018). Nearly all the IDP camps have similar trends of shortages of food, poor healthcare facilities, insecurity, oppression, water challenges and sanitation challenges. Medecins Sans Frontieres describes the ordeals of the IDPs as pathetic, explaining how basic living needs have not been met. The camp located at Abuja Area One was once described as a place of tears and uncertainty (Nwabughiogu, 2015). The camp, along with three others, was declared unfit for human habitation due to their excruciating living conditions (Mohammed, 2018; Nwabughiogu, 2015). According to Catholic Relief Services (2020), "Camps in northeast Nigeria are overcrowded, poorly planned, lack hygiene infrastructure and can become havens for disease and infection."

Food and water are basic prerequisites for sustenance and survival in IDP camps, and should be readily available. The food should be balanced and sufficient. The camps suffer from acute shortage of food and poor shelter (Haruna, 2018), which has created serious problem of malnutrition (International Committee of the Red Cross, 2016). The level of malnutrition has led to the death of many children and other vulnerable people like women and the elderly (International Committee of the Red Cross, 2016). In January 2021, the governor of Borno State raised alarm over shortage of food for IDPs, and appealed to NEMA to provide food for over 80,000 starving IDPs (Musa, 2021). Displaced persons in the camps need shelter to promote their well-being, health, privacy and for protection against harsh weather conditions. Shelter is not enough, as many of them are housed in schools and other public buildings. Some of the IDPs live in small, overcrowded makeshift shelter, while others put up in prefabricated home. Overcrowding is a major challenge, occasioned by severe shelter deficit (ECHO, 2019).

Camps for IDPs should be in good state of hygiene and sanitation in order to maintain health and prevent diseases. In this regard, IDPs should have access to personal hygiene items as this would diminish exposure to diseases such as typhoid, cholera dysentery and diarrhea. The camps lack amenities in particular, potable water, proper hygiene and safe disposal of human waste (Ekezie et al., 2021). Essential hygiene items like buckets and soap are scarce. There is dearth of knowledge about personal hygiene and environmental sanitation, as most people still indulge in open defecation.

Outbreak of cholera and tuberculosis in the camps, leading to deaths, is a regular occurrence (Catholic Relief Services, 2020). This is not surprising, considering the poor hygienic conditions in the camps. The IDPs should be educated on how to maintain good hygiene and sanitary practices. The emergence of Covid-19 presents a unique challenge. According to UNICEF (2020a) "IDP camps are crowded, with little room for social distancing." Sexually transmitted infections, including HIV and AIDs have been on the rise in the camps (Abdullahi et al., 2020; Family Health International 360, 2015; Premium Times, 2017). The leading causes are sexual transactions for survival and gender violence (Nsikan et al., 2020). Children have also suffered diarrhea and cholera caused by the poor living conditions they are exposed to (ICRC).

The camps lack security (Schlein, 2018). The civilian population, including IDPs, must be protected against, and be free from, all forms of threats or violent situations. Safety has been a major issue in the camps. Poor security has exposed IDPs to attacks by insurgents and armed elements from host communities, which has led to deaths and further displaced many more to places unknown. Women and girls sometimes offer sexual gratification in order to guarantee their protection (Donald, 2021). With the deployment of the military and sundry forces, the issue of insecurity should have been the least expected, but it has become a recurring decimal in these camps. Host communities have in many instances attacked IDPs, especially because of the porous security situation in these camps, resulting in injuries and sundry damages (Kamta and Scheffran, 2021). Host communities feel threatened that their lands have been seized and handed over to people. The government has a duty to provide adequate security in the camps.

\subsection{An Epidemic of Sexual Exploitation and Abuse}

Rights of IDPs in Nigeria are constitutionally guaranteed, but in most cases, they are not respected in the administration of the camps. Human rights law and IHL also provide protection and care for victims of armed conflict, including IDPs (International Committee of the Red Cross, 2017; United Nations, 2007). Apart from failures in the provision of shelter, food, water and hygiene, and security, the government has failed to prevent rape, sexual exploitation and other infractions against IDPs in the camps (Alliances for Africa, 2021; Women' Media Center, 2021). The camps have been characterised by oppression and all forms of maltreatment from security operatives and other groups mandated to provide protection (Human Rights Watch, 2016).

Grave human rights abuses against women and girls are prevalent in the camps (Ugwa, 2021). It was reported that a large number of females in the camps are sexually assaulted by camp officials, including soldiers, police and vigilante groups (Asadu, 2018). Human Rights Watch (2016), reported several incidents of sexual abuse in camps in Maiduguri, including four females who were drugged and raped. A young lady was reportedly raped by a police officer, after refusing the sexual relationship. Women and girls have been forced into sexual relations in interchange 
for essential needs (Donald, 2021). Ladies give in to illicit requests to enable them secure some concessions in the camps (Ugwa, 2021). In a place where meal is rarely served, ladies readily give in to male advances in order to secure food.

Sexual abuses have been identified as the primary apprehension in all IDP camps (Donald, 2021). The explanation is that sex is the muster point for many concessions, such as freedom of movement, access to food, protection and so on. Demands for transactional sex to facilitate access to basic items are commonplace (UN Human Rights Council, 2017). This is the commonest form of survival strategy in IDP Camps (NAN, 2019). Sexual exploitation also involves women being swindled, lured, and induced by fake promises of marriage and support (Human Rights Watch, 2016). Many of them were abandoned when they became pregnant. Girls are forced into sexual relations with officials and many get pregnant. They are usually afraid to report due to reprisal attacks. Women and girls who have been raped suffer shame and stigma. Victims are reluctant to seek health care, including psychological counselling, due to the shame $t$ and guilt.

Sex for freedom of movement is another form of exploitation perpetrated in the camps. Despite the guarantee of such freedom in Principle 14.2 of the UN Guiding Principles, IDPs still suffer severe restrictions (Human Rights Watch, 2016). Women and girls who enjoy such right have to pay for it sexually. The restriction on freedom of movement placed on IDPs has resulted in its use as an exploitative tool by military personnel in these camps.

Children constitute 60 per cent of the thousands of displaced people in the camps (UNICEF, 2020b). Many of them are orphans, unaccompanied or household heads (Obaji, 2018). These children, who also live in excruciating conditions, have had their rights violated in various ways (Adelakun, 2021; Vittozzi, 2016). Many are traumatized, malnourished, dehydrated and exposed to sexual and gender-based violence (Vittozzi, 2017); and have literally lost their childhood (Ating, 2020). Underage girls are sexually abused and raped, resulting in pregnancies (Dickson, 2015). Children in the camps have no access to education and this further worsens the problem of out-of-schoolchildren in northern Nigeria. Girls are seen as an economic burden. Some as young as 12 are compelled to marry to enable them feed and to provide for their parents. The bride price for the girls provides much needed income for the parents.

There are also reports of human trafficking in IDPs camps. Women and children in the camps are vulnerable to trafficking. Human traffickers make overtures to the girls, mostly orphans, promising them good jobs and quality life in Europe (Obaji, 2018). Hundreds of children are taken away from the camps and sold to buyers from Lagos and other parts of Nigeria (Dickson, 2015); and used as prostitutes or domestic servants wherever they find themselves. Other vulnerable persons, who are susceptible to the antics of the kidnappers, are separated and unaccompanied children (Obaji, 2018). A victim accused government officials of complicity in trading in children (Dickson, 2015).

\subsection{Corruption, Lack of Accountability and Failure of Government}

The nasty experiences of IDPs are attributable to key factors, principally the failure of government. Government has the capacity to nip these violations in the bud and win the confidence of the victims. However, it has failed to offer such protection. State officials responsible for the management and safeguard of the camps seem to have done nothing to address the plights of the IDPs. The National Agency for the Prohibition of Trafficking in Persons (NAPTIP) has condemned allegations of sexual abuse and trafficking in the camps, describing them as crimes that should not be ignored (NABTIP, 2018). The agency said it was working to protect IDPs from traffickers. Though NAPTIP has been vociferous in the condemnation of human trafficking and gender-based violence in the camps, its efforts have not yielded any tangible result leading to prosecution. The void created by government inaction was filled by humanitarian actors, led by IOM, which established Anti-Trafficking Task Force to tackle the scourge (International Organization for Migration, 2019).

Government huge expenditure has not recorded any significant impact as complaints by the IDPs persist. The PCNI has allegedly spent whopping billions of naira on foodstuffs and catering materials, shelter, medical supplies, and other humanitarian needs of the IDPs (Ameh, 2018). Yet there is no food, no water, no healthcare and schools for the children. Indeed, life is very tough and miserable for them. This state of affairs in the camps is largely due to corruption by government officials, who divert most of the aids and sell them in the open market. Scantiness of accountability has undoubtedly promoted impunity and emboldened perpetrators of crimes in the IDP camps. Refusal or hesitation to sanction persons implicated in sexual exploitation in the camps only serves to encourage them. Many organisations have published indicting documents against the perpetrators of human rights abuses, but none has been made to face sanctions, thereby denying justice to the victims (Donald, 2021).

\subsection{Invoking the Doctrine of Individual Criminal Responsibility}

The foregoing narrative evidently highlights serious violation of national and international laws in force in Nigeria, which protect victims of armed conflict and prohibit acts of violence against women and girls, such as those perpetrated in the camps. The Violence Against Persons (Prohibition) Act 2015, a local legislation, was enacted to protect citizens and their rights, as well as prescribe punishment for violations. The mistreatment of children in the camps constitutes a gross violation of the Child Rights Act 2003, which guarantees the rights of Nigerian children. The Rome Statute of the International Criminal Court categorizes "rape, sexual slavery, enforced prostitution, forced pregnancy or other forms of sexual violence" as war crimes (Art. 8) or crimes against humanity (Art. 7), and holds individuals criminally responsible for their actions irrespective of status (Rome Statute of International Criminal Court document A/CONF 183/9, 1998).

The doctrine of individual criminal responsibility for crimes committed in situations of armed conflict applies to violations in the IDP camps (Greppi, 1999). Sexual violence against IDPs and other victims of the insurgency are 
punishable as war crimes or crimes against humanity under current international law (International Committee of the Red Cross, 2015). Military and civilian officials implicated in rape and sexual violence against IDPs should bear criminal responsibility for their actions as typified by the conviction of military personnel in charge of detention camps in the Yugoslav conflict, for their involvement in sexual crimes against detainees (Prosecutor v Furundzija Case No. IT-9-9171A, Judgment (July 21, 2000); Prosecutor v Zenjnil Delalic, Zadravko Mucic, Hazim Delic and Esad Landzo, Case No. IT-96-21 (Celebici Camp Case).

\subsection{A Bleak Future for the IDPs}

Displaced persons in the various camps across northeast Nigeria and beyond face a bleak future. Firstly, they are unable to go back to their communities because the insurgents are still active and had attacked many who attempted to do so in the past. Secondly, the authorities have paid little attention to the issue of IDPs, reneging on most of their obligations under the 2012 National Policy; UN Guidelines on Internal Displacements, 2004; and the Geneva Conventions and Additional Protocol II of 1949 and 1977 respectively. The government is presently concentrating on resettling and rehabilitating repentant Boko Haram members.

Some measures would be useful in bringing lasting solutions to the plights of IDPs. Government should improve conditions in the camps by providing enough humanitarian aids and punish corrupt officials involved in mismanagement and diversion. The impact of corruption in all facets of the social construct is too serious to be treated with kid gloves, because it is the foundation of other forms of misbehaviour. Government should rejig security and tackle the hostility of host communities to IDPs by working with community and youths leaders to embrace these IDPs as fellow compatriots and victims of circumstances. The well-being of soldiers, especially those protecting the camps and others engaged in the fight against insurgency, should receive uppermost attention (Obasi, 2015). Their motivation to work must remain high. Civilian and security officials in charge of IDPs camps should be trained in human rights and humanitarian law. Personnel accused of oppressing and exploiting IDPs, in the form of survival sex and other favours, should be sanctioned as a deterrent. Civil society organizations should intensify efforts in drawing international attention to the hardship and exploitation faced by the IDPs.

\section{Conclusion}

Internal displacement engendered by the insurgency remains a major problem in Nigeria. The failure of government to protect IDPs or meet their basic needs is giving the nation a negative national and international publicity. Government should do more to ensure that officials vested with responsibility deliver on their mandate and discharge it with utmost sincerity. This should be accompanied by effective checks and monitoring system, with the assistance of external bodies such as ICRC, UNICEF, Amnesty International or other humanitarian organizations, to maintain `n high standards and ensure observance of humanitarian norms. Ultimately, the smooth, peaceful and safe return of the IDPs to their traditional lands is fundamental. This is possible if the insurgency and general insecurity are brought to a logical conclusion. The persistent sacking of communities by Boko Haram and bandits would continue to exert unnecessary pressure on the IDPs.

\section{References}

Abdullahi, S. A., Smelyanskaya, M., John, S., Adamu, H. I., Ubochioma, E. and Kennedy, I. (2020). Providing TB and HIV outreach services to internally displaced populations in Northeast Nigeria: Results of a controlled intervention study. PLoS Med, 17(9): e1003218.

Adelakun, O. (2021). Internally displaced children in Nigeria: A rights-based situational appraisal in romola adeola (ed.) national protection of internally displaced persons in Africa. Springer International Publishing.

Alliances for Africa (2021). International day for the elimination of sexual violence in conflict. Available: https://alliancesforafrica.org

Ameh, J. (2018). IDPs: Buhari's panel spends N6bn on foodstuffs refreshment, others. Available: https://www.google.com/amp/s/punchng.com/idps-buharis-panel-spends-n6bn-on-foodstuffs-refreshmentothers/amp/

Asadu, C. (2018). Amnesty: Soldiers raping women in IDP camps...thousands starving to death. Available: https://www.thecable.ng/amnesty-thousands-starved-death-soldiers-raping-women-idp-camps/amp

Ating, N. (2020). Lost childhood: The trauma of growing up in Nigerian IDP camps" International Centre for Investigating reporting. Available: https://www.icirnigeria.org

Campbell, J. (2014). Boko Harem; Origins, Challenges and responses" NOREF Norwegian peace building resource centre policy brief, October.

Catholic Relief Services (2020). Water, sanitation and hygiene for Nigerian camp. Available: www.crs.org/stories/water-sanitation

Dickson, C. (2015). Investigation: Grim tales of rape, child trafficking in Nigeria's displaced persons camps" Premium Times January 31. Available: www.premiumtimes.com>176005.

Donald, I. (2021). Abuse of women in IDPs" The Guardian 18 April. Available: https://guardian.ng/opinion/abuseof-women

ECHO (2019). Nigeria - overcrowded internally displaced people camps (dg echo, un, ngos)(echo daily flash of 8 february 2019). Available: https://reliefweb.int 
Ekezie, W., Myles, P., Murray, R. L., Bains, M., Timmons, S. and Pritchard, C. (2021). Self-reported diseases and their associated risk factors among camp-dwelling conflict-affected internally displaced populations in Nigeria. Journal of Public Health, 43(2): e171-e79.

Family Health International 360 (2015). Assessment of hiv/aids services in idp camps, borno state, Nigeria. Available: https://www.fhi360.org/resource/assessment-hivaids-services-idp-camps-borno-state-nigeria

Global IDP Project (2002). Background information on the IDP situation in Nigeria. Available: https://reliefweb.int/report/nigeria/background-information-idp-situation-nigeria

Goetz, N. H. (2001). Humanitarian issues in the Biafran conflict new issues in refugee research working paper no. 36 pepperdine university school of public policy California.

Greppi, E. (1999). The evolution of individual international criminal under international law. International Review of the Red Cross: 30-09, No. 835. Available: https://www.icrc.org/en/doc/resources/documents/article/other/57jq2x.htm

Haruna, S. (2018). IDPs lament inadequate food, poor shelter in Borno as PCNI completes assignment in less than one year" International Centre for Investigative Reporting. Available: https://www.icirnigeria.org/idpslament-inadequate-food-poor-shelter-in-borno-as-pcni-completes-assignment-in-less-than-one-year/amp/

Human Rights Watch (2016). Nigeria: officials abusing displaced women, girls. Available: https://www.hrw.org/news/2016/10/31/nigeria

Ibanga, M. and Archibong, J. (2018). the boko haram insurgency: Characterisation and implications under municipal and international laws in j. Iyi and h. Strydom (eds) boko haram and international law. Springer: Cham, Switzerland.

Ibeanu, O. (1998). Exiles in their own home: Internal population displacement in Nigeria. The African e-Journals Project, 3(2).

International Committee of the Red Cross (2015). Prevention and criminal repression of rape and other forms of sexual violence during armed conflicts. Available: https://www.icrc.org

International Committee of the Red Cross (2016). Critical food shortage for those fleeing conflict in North East Nigeria. Available: https:/www.icrc.org/en/document/nigeria-disease-idp-conflict-malnutrition\%3famp

International Committee of the Red Cross (2017). Internally displaced persons and international humanitarian law Factsheet. Available: www.icrc,org/en/document

International Organization for Migration (2019). Humanitarian actors establish first anti-trafficking task force in North-East Nigeria" Reliefweb 12 July available at reliefweb.

International Organization for Migration (2021). Northeast nigeria: Displacement report 38 (october 2021). Available: https://reliefweb.int>report>north

Kamta, F. N. and Scheffran, J. (2021). A social network analysis of internally displaced communities in northeast Nigeria: potential conflicts with host communities in the Lake Chad region" GeoJournal. Available: https://doi.org/10.1007/s10708-021-10500-8

Mohammed, H. (2018). Thousands displaced by Boko Haram languish in Abuja IDP camps. Available: https:/www.aljazeera.com/amp/indepth/features/thousands-displaced-boko-haram-languish-abuja-idpcamps-180325070133915.html

Musa, N. (2021). Over 80,000 IDPs need food in Borno - Zulum m.guardian. Available: www.m.guardian.ng/news/over-80000

NABTIP (2018). NABTIP DG spits fire over allegation of sexual abuse in IDP camps.

NAN (2019). Check human rights violations at IDP camps, NGO tells government" m.guardian. Available: https://www.guardian.ng/features/health/check-human-rights-violations-at-idp-camps-ngo-tellsgovernment/amp

National Policy on Internally Displaced Persons in Nigeria (2012). Federal Republic of Nigeria. Available: https://www.refworld.org

Nextier SPD (2020). Nigeria's displacement dilemma reliefweb. Available: www.int/report/nigeria

Nsikan, A., Sunkanmi, F., Yunana, P. and Adamu, J. (2020). Prevalence of HIV in north-east Nigeria: A case of comprehensive HIV service delivery in 3 internally displaced persons camps in Borno State. International Journal of HIV/AIDS Prevention Education and Behavioural Science, 6(2).

Nwabughiogu, L. (2015). Abuja area one IDPs camp: A place of tears, uncertainty" Vanguard. Available: www.vanguardngr.com $/ 2015 / 03$

Obaji, P. J. (2018). In north-eastern Nigeria, traffickers are preying on vulnerable children in IDP camps. EQUAL TIMES: Available: https://www.equaltimes.org/in-noth

Obasi, N. (2015). The soldiers are less motivated than the Boko Haram insurgents. Available: https://www.crisisgroup.org/africa/west-africa/nigeria/soldiers-are-less-motivated-boko-haram-insurgents

Okon, E. O. (2018). Internally displaced persons in Nigeria: Review of empirical studies. American International Journal of Social Science Research, 2(1): 28-38.

Olarenwaju, F. S., Olarenwaju, A. and Femi, O. (2019). Insurgency and the invisible displaced populations in Nigeria: A situational analysis. Sage Journals: Available: www.journals.sagepub.com

Premium Times (2017). Borno records 3,800 new cases of HIV in IDPs camps. Available: https://www.www.premiumtimesng.com/regional/nnorth-east/228028-borno-records-3800-new-cases-hividps-camps.html/amp/ 
Rome Statute of International Criminal Court document A/CONF 183/9 (1998). see also statutes of international criminal tribunal for the former yugoslavia (Article $5(\mathrm{~g})$ ), international criminal tribunal for rwanda (Art. $3(\mathrm{~g}))$, and Special Court for Sierra Leone.

Sahara Reporters (2018). Huriwa: Neglect suffered by idps, worst case of human rights violations. Available: http://saharareporters.com/2018/09/24/huriwa-neglect-suffered-idps-worst-case-human-rights-violations

Schlein, L. (2018). UN urges nigeria to bolster protection in borno state idp camps" VOA. Available: https://www.voanews.com/africa/un-urges-nigeria-bolster-protection-borno-state-idp-camps\%3famp

Ugwa, J. (2021). Sexual abuse thrives in Nigeria's IDP camps with no recourse for victims wmc women under siege.

UN Human Rights Council (2017). Report of the special rapporteur on the human rights of internally displaced on his mission to Nigeria Reliefweb 12 April (A/HRC/35/27/Add.1) available at reliefweb. Available: www.int/report/nigeria

UN Office for the Coordination of Humanitarian Affairs (2004). Available: www.unocha.org

UNICEF (2020a). Displaced children navigate COVID-19 in camps in north-east Nigeria. Available: www.unicef.org/nigeria/stories/

UNICEF (2020b). 19 million children internally displaced by conflict and violence in 2019 is highest number ever, says UNICEF. Available: https://www.unicef.org

United Nations (2007). Handbook for the protection of internally displaced persons global protection cluster working group. Available: https://www.un.org

United Nations High Commissioner for Refugees (UNHCR) (1998). Guiding Principles on Internal Displacement ADM 1.1, PRL12.1 PR00/98/109. Available: https://www.refworld.org/docid/3cda07f7.htm

Vittozzi, K. (2016). Umara's story: After Boko Haram, children in Nigeria are starving. Available: https://www.one.org/africa/blog/umaras-story-after-boko-hara

Vittozzi, K. (2017). 400,000 children in north-east Nigeria at risk of severe acute malnutrition UNICEF. Available: https://www.unicef.org

Women' Media Center (2021). Sexual abuse thrives in nigeria's idp camps with no recourse for victims reliefweb 20 may. Available: www.int/report/Nigeria/ 